\title{
An Editorial on Academic Freedom to Preserve Liberty in Teaching ${ }^{i}$
}

\author{
Robin S. McCutcheon
}

Lewis College of Business, Marshall University, United States

Copyright $\odot 2019$ by authors, all rights reserved. Authors agree that this article remains permanently open access under the terms of the Creative Commons Attribution License 4.0 International License

\begin{abstract}
The noble task of teaching requires a free spirit of inquiry, exemplary open-mindedness, and conditions for the practice of responsibly relaying information to the student. (Justice Frankfurter, 1952) For the last century, academics have supported the idea of a 'free spirit of inquiry' and have dubbed it academic freedom. In the current divisive climate between progressive and capitalist ideologies, having and keeping your academic freedom requires you to understand what academic freedom is, where it came from, and why it is important to defend it. Our students often don't hear the message of capitalism because the numerical majority of professors, across all disciplines, are progressive. In order for students to make rational decision about capitalism, they have to be taught about it by professors who are capitalists. More open dialogue, not less, between professors holding different ideologies, in front of an audience of students, is necessary.
\end{abstract}

Keywords Academic Freedom, Socio-economic Political Systems, History of Thought

\section{Introduction}

"Congress shall make no law respecting an establishment of religion or prohibiting the free exercise thereof, or abridging the freedom of speech or of the press, or the right of the people peaceably to assemble and to petition the government for a redress of grievances." Amendment 1, U.S. Constitution, ratified December 15, 1791

The noble task of teaching requires a free spirit of inquiry, exemplary open-mindedness, and conditions for the practice of responsibly relaying information to the student. (Paraphrasing Justice Frankfurter's Opinion in Wieman v. Updegraff, 344 U.S. 183 (1952) in Levinson, 2007)

From time to time it behooves us to take a historical look back to review what has transpired in academic literature and in society. It is generally assumed that academics are unbiased in teaching or research, but the truth is, we are not. The bias begins with the fundamental ideology each of us holds dear. For example, the founding principle of capitalism, that the individual is paramount and society cannot demand that he sacrifices himself to it, is the exact opposite of the founding principle of socialism, that society is paramount and the individual must subsume himself to it. Adam Smith's invisible philosopher silently observing the world without causing it to alter is diametrically opposed to Karl Marx's demand that the philosopher's job is to change society. (Smith, 1776; Marx, 1845; Marx \& Engels, 1848) Whereas Smith's philosophy leads to a type of political economy we call free market capitalism, Marx's philosophy leads to a type of political economy known by many names: communism, socialism, progressivism, etc. But perhaps we can leave it as 'progressivism' since the tendency of people on that side of the argument is to change the name as soon as too many of the common folk realize that what's happening to them is their free choice has been stolen, as well as their money, and they are being forced to submit to an over-grown government. ${ }^{1}$

In academe, because progressive professors outnumber capitalist professors about 100-to-1, the 'losers' in this competition for ideas are the students, who rarely hear pro-Capitalist, pro-American ideas expressed in their courses; they generally hear only progressive messages from their professors. (Gross and Simmons, 2007) Some academics attribute the beginning of the century-long struggle for academic freedom to philosophers and economists. (Shaffer, 2010) It is immaterial who started the ideological pendulum swinging, what matters is that academics who wish to teach free market capitalism use the

1 I use the word 'progressivism' to refer to any socio-economic and political system wherein the individual is not free to be self-determinant. I include all forms of top-down authoritarian philosophies, such as socialism and Marxism, since at its root all forms of authoritarian '-isms' are tyrannical. I am using all of these words interchangeably to describe non-free market ideology. 
principle of academic freedom so that our students can hear pro-American, pro-Capitalist ideas. With that in mind, I offer readers a brief backwards glance at the last hundred years, or so, of the history of academic freedom, in order to glimpse how the swinging pendulum of ideology within the scope of academic freedom got started, where it is now, and how we can use this information to form effective, pragmatic strategies to protect and teach capitalism.

\section{A Tale of Two Ideologies}

The battle of competing ideologies is a dogmatic fight between two types of academics, and the ideological fight starts with Adam Smith. ${ }^{2}$ (1776) Smith noted the founding principles put forth by the colonists in the New World were far different from anything on the European Continent. He forecasted that the principles of freedom supported by the colonists, and market forces unleashed, would build an economic and political system entrenched in individual freedom and liberty. Smith never called Americans capitalists -he called them industrialists; he merely noted that the colonists in the New World were creating a form of government, society, and economy built on freedom of speech and freedom of industry. (Smith, 1776)

It is important to recall that in Europe, up to and beyond Smith's time, the majority of universities were founded by the Church, or sometimes the country's ruling monarch. University curricula included teaching Christian principles, and the importance of knowing one's place, the serf subjugating himself to the monarch, society, or the community. University pupils were sons of the nobility and merchant wealthy only, and in the fullness of time, were expected to take their place in parliament or the upper echelons of government. There were no teachings of the importance of the individual or freedom of choice for anyone of non-noble birth. The state, or the monarch, commanded all. In Europe, this was the 'conservative view.' Prior to the mid-1800s in Europe, if in your opinion, opportunities should exist for everyone, even those of non-noble birth, you were considered 'liberal minded.' (Smith, 1776; Marx 1848; Rand, 1957) Your station in life depended on who your parents and ancestors were, and was unchangeable. You would never be able, or allowed, to rise above your station. The economy and markets were totally regulated and run by the monarch; there was no such thing as 'the free market'. (Johnson, 1998)

2 Type 1: Academics who believe in a socio-economic political system designed for maximum freedom and liberty (a.k.a. capitalism) and teach students that their lives will be better with a capitalistic system and worse under all other systems.

Type 2: Academics who believe in a command and control socio-economic political system (a.k.a. progressivism, socialism, communism, ..., the list of anti-Capitalist, anti-free market, names for command-and-control economies is long) and teach the same group of students as the Type 1 professors that it is only with their command and control system that students' lives will be better.
But, this was not so in America. The reader needs to remember that during the 1800s, in America, Christian churches founded the majority of American colleges and universities. (Gross and Simmonss, 2007; Hutcheson, 2018) Faculty were charged with teaching Christian principles, the importance biblical teachings played in the writing of the Declaration of Independence and the U.S. Constitution, and how the American way of life depended on the individual knowing his Unalienable Rights and being independent and self-governing. (Gross and Simmonss, 2007; Hutcheson, 2018) University pupils were the sons (and sometimes daughters) of Americans of all walks of life; anyone could attend university. The American free market economy was unregulated, wild, chaotic, and offered incredible opportunity to anyone willing to work, regardless of station in life or origin of birth, to earn vast amounts of wealth. (Johnson, 1998) By the end of the 1800s, this ideology became known as American conservatism. $^{3}$ (Gross and Simmons, 2007) If your opinion strayed from conservatism, you held 'liberal views' and were considered 'progressive.'

Seventy-five years after America's founding, in the mid-1800s, Karl Marx lamented that the American industrialist was materialistic, opportunistic, overly wealthy, and derogatorily labeled them capitalists. He insisted that the wealth created by the industrialists was stolen from their workers, and thus ought to be redistributed amongst the poor. In Marx's philosophy, the only way to get wealth was to steal it - paying your workers piecemeal formed a type of theft - that workers and factory owners were earning wealth through trade never occurred to him. (Marx \& Engels, 1848; Rand, 1957) Marx fundamentally misunderstood how free markets work and how wealth is created in the organizing of his philosophy. (Johnson, 1989) Marx's philosophy, 'from each according to his ability to each according to his need' and 'the ends justifies the means', bubbled up from a Euro-centric market ideology, a market controlled by the state or small group of intellectuals, infiltrated European universities from 1850 onward, and mesmerized influential American academics who brought it to US universities in the late 1800s. (Gross and Simmons, 2007; Hutcheson, 2018) In America, this ideology was 'progressive' because it fundamentally moved away from 'conservative' free market thought. (Gross and Simmons, 2007)

Keep in mind that at the end of the nineteenth century and beginning of the twentieth, the majority of US professors were natural-born Americans teaching at American universities. (Johnson, 1998) The progressive versus free market ideological fight was between American professors who held capitalism near and dear, who

3 At some point, someone is going to point out the issue of pre-Civil War slavery. That's a topic I'll leave for another paper. 
numbered in the vast majority, and American professors who held progressivism near and dear whose numbers was a very tiny minority. (Gross and Simmons, 2007)

As the few American faculty enamored with Marx's philosophy, began introducing and teaching progressivism to their students at university, a panic gripped administrators and conservative donors. They knew that progressivism was fundamentally, diametrically opposed to American conservativism and free market economics. Offered as 'Continental', 'sophisticated' and European, students flocked to this 'new' ideology. (Johnson, 1989) It didn't take a crystal ball to forecast that should progressivism be taught, and should students adhere to it as solidly as they did American values, it would flourish and eventually supplant American conservative ideology. (Johnson, 1989)

So, during the first decade of the 1900s, universities began dismissing some prominent professors because they were teaching anti-American ideas. This was an effort to keep American students from learning anti-American, anti-Capitalist, progressive ideologies. (Gross and Simmons, 2007; Hutcheson, 2018) In response to these dismissals, in 1915, affected professors formed the American Association of University Professors (AAUP), a union designed to protect the freedom of speech of all professors, but in particular, professors whose ideology was anti-American and anti-Capitalist in nature. (Gross and Simmons, 2007; Levinson, 2007) The AAUP, standing on the First Amendment of the U.S. Constitution, issued its Declaration of Principles on Academic Freedom and Academic Tenure (known now as ‘the Declaration'). 4 The Declaration claimed that all academics, regardless of ideological inclination, had the right to speak freely within their discipline in the course of teaching their students. This was early in the twentieth century, when the 'free spirit of inquiry' was given the name academic freedom. (Levinson, 2007) With this Declaration, the AAUP created a safe zone for progressive professors within the university system. (Gross and Simmons, 2007)

By the mid- $20^{\text {th }}$ Century, after two world wars and the still-living memory of how closely Americans had come to losing their liberty to Nazis, fascists, and communists, and during the McCarthy-era 'red scare', a great effort was made by capitalist university donors, conservative university administrators, and free market economics professors to, once again, try and rid their universities of progressive ideology once and for all. (Gross and Simmons, 2007; Levinson, 2007; Shaffer, 2010) It was considered un-American to spout liberal, progressive, socialist, Marxist, or communist ideology in any form or format, or to be associated with un-American organizations. (Gross

4 The three principles supported by this document encompass academic freedom and are: freedom of inquiry and research; freedom of teaching within the university or college; freedom of extramural utterance and action. (Shaffer, 2010) and Simmons, 2007; Shaffer, 2010) Americans did not want their children learning progressive ideology because of the known disaster it would cause to their way of life.

During this time period, progressive professors, vastly outnumbered by their capitalist colleagues, were having their freedom of speech silenced and their academic freedom squelched. This resulted in a number of prominent Supreme Court cases and law suits between progressive professors and their respective universities, and the progressive professors won. Thereafter, colleges and universities began writing policy bestowing academic freedom on faculty, including the freedom to choose course materials, administer lectures, give speeches and associate with 'subversive' organizations. These policies were considered contractual, and during the 1960s additional court cases wherein the settlements upheld the academic freedom of progressive professors, became the norm. (Gross and Simmons, 2007; Levinson, 2007)

For the next seventy years, progressive professors used the shield of academic freedom and the tenure process to eradicate pro-Capitalist professors from university. This mirrors the McCarthy-era actions by pro-Capitalists, except that the characters doing the silencing were now progressive academics. (Gross and Simmons, 2007; Moynihan, 2017; Herzog and Vielmetti, 2018; Volokh, 2018; Piper, 2018) As feared by turn-of-the-century academics, and unnoticed by the general public, progressive professors have become the numerical majority, and the ideological pendulum has swung to the left. (Gross and Simmons, 2007)

\section{Using Academic Freedom to Illustrate Both Ideologies for Students}

If you are observant of history, you will notice that, in the past, the tendency of professors in the numerical majority has been to try and silence their ideological opponents in the numerical minority. Professors worry that their ideological opponents will propagandize students through their teaching and assignments, and lure them into the opposing ideology. My personal observation is that progressive professors use their lectures and assignments to sway student opinion of capitalism to the negative, while at the same time offering no conclusive evidence or data that progressivism is a superior economic and political system. They laud the fuzzy, good feelings students will have by adopting facets of progressivism ('we should do it for the collective good,' 'progressive policies are good for the common welfare' are two I've heard lately), my ideological opponents rarely pause to give students the facts and evidence of the deplorable results progressivism has when implemented in an economy.

In an attempt to capture student's attention and loyalty, I design lectures to focus on the data and evidence from 
progressive (socialist, communist, and totalitarian) countries to illustrate and prove that progressivism has despoiled entire countries of wealth, independence, freedom, and liberty, delivering entire populations into modern-day slavery to the state, and proving that capitalism is the best path to freedom and prosperity.

Back and forth my ideological opponents and I wage the intellectual battle. Trapped in the middle are the students required to take my courses and the progressive's courses. The student's opportunity cost of attention time is at a premium; they never seem to soak in the whole story. Often, sadly, by the time students appear in my upper-level courses, they have stopped caring which side is right. I have concluded that this battle of ideas, where one side wants to silence the other, wherein the students' attention and loyalty is at stake, does not work!

What we have seen little of is an open dialogue between progressives and capitalists with the students listening to the entire conversation. In the fall of 2017, a colleague of mine, who is my ideological opponent and a professor of Sociology, and I attempted to bury the hatchet by stopping our attempts to silence each other (or out shout each other) by coordinating a series of seven workshop debates with the overall topic of Adam Smith and Karl Marx: "Individualism versus Collectivism.” We each chose three of the seminal philosophers in our field (I chose Adam Smith, Ludwig von Mises and Thomas Sowell; my colleague chose Karl Marx, Harry Braverman, and Thomas Piketty) and offered a brief lecture touching on the basic theme of each philosopher's ideology. Students and faculty attending the workshop series asked questions, argued points, but most often, requested more clarification about the economic outcomes each ideology proffered. It was a brilliant success and failure. For my colleague, even though he thoroughly enjoyed the workshops, it was a failure, because while the socialist-progressive students vastly outnumbered the capitalist students in the first few workshops, by the end of the series there were no socialist students left to argue that collectivism (socialism, progressivism, etc) was a superior economic and political system to individualism and capitalism.

It was a brilliant success because students could see and hear the ideologies, side by side, and they beat a path to the ideology offering the maximum amount of economic and political freedom: capitalism. The students holding the progressive (socialist) ideology faded away. They stopped attending the workshop. That's what I mean when I say that the prize, in the competition of ideas, is in influencing the students we teach.

In the course of teaching economics, my audiences of First Year and Second Year students always seem a bit surprised at the deleterious economic outcomes for individuals and communities once a progressive government takes over an economy. For they have heard nothing but platitudes from their progressive professors about how great socialism and progressivism are; they are never taught how capitalism has made America great and wealthy. Very often, by the time students take my economics courses, they have already taken an Introduction to Sociology course. At first, I was horrified to find that they were taught that American greatness is unearned and the wealth was stolen, and all of that was the fault of capitalism! Students are hardly ever shown the actual economic and political outcomes that occur to people when a country implements progressive ideology. So, the textbook that I use must be written with an eye towards nullifying the indoctrination the Sociologists wrought.

As a free market economist, I know that when all the ideas are presented, the best ideas will eventually win out. All that is needed is a fair hearing. If we could sell progressivism and capitalism in the marketplace, like a good or service, then the forces of demand and supply would determine what price and quantity would be produced of each. Of course this example is ludicrous, because these are ideologies and the only way for the audience to choose which ideology suits them best is to hear both sides, and see the logical outcome of implementing each system in countries across the world. Perhaps the market for textbooks could give a good example of which ideas are gaining traction.

In 2017, the number one principle of economics textbook in the United States, written by two free market economists, was adopted at nearly 1600 institutions of higher learning. The second and third most popular principles of economics textbooks, combined, was adopted at 667 institutions of higher learning. The market sale of the number one textbook is five times greater than the number two textbook, and nearly ten times the number of the third place textbook. In the marketplace for principles of economics textbooks, consumers have beaten a path towards free market economics. I also use this book, because in addition to being very clearly written, the authors have illustrated the century-long folly of implementing progressive economic policies. After all, the twentieth century is replete with examples of how progressivism in the form of socialist, fascist, and communist (to name a few) governments ruin 'wealthy' countries' economies. The governments of Russia (1917-1990), Cuba (1959-present), and Venezuela (1996-present) are a few good examples of the deleterious effects progressive economic policies have on a country's citizens. People suffer when these ideologies are implemented in their country's economy.

This is where one must be vigilant, for a violation of academic freedom can happen in small, unnoticeable ways, too. If your institution supports academic freedom, check the policies to verify that that freedom includes individual instructor choice of textbook. Violations of your academic freedom can occur if you are forced to use a textbook that you don't want to use.

But the most effective way to change a student's mind 
about progressive-socialism is to touch them emotionally. I've observed that students aren't really emotionally moved by data, so I show them the results of progressive policies. Last spring, I showed pictures of the Venezuelan zoo animals from 2017. The animals were skeletal and suffering from starvation. Some of the animals were dead, their remains left where they'd fallen, skeletons covered by some bits of fur. Students were in tears, as I explained how the progressive-socialist government didn't have the money to buy food for the poor zoo creatures. I showed them pictures of cats and dogs on the streets of Caracas, and of Venezuelans butchering their pets to eat them. Students told me later, it made a difference in their stance on progressive-socialist ideology.

\section{Conclusions}

The concept of academic freedom and tenure, born from the early twentieth century fight between capitalist and progressive academicians, was designed and written by progressive professors to preserve their positions at university. Progressive professors then used these rules over the course of the $20^{\text {th }}$ Century to rid themselves of competing ideologies. After one hundred years, in a survey of professors across all disciples, in over 180 colleges and universities, the percentage of moderate to center-left to far-left professors exceeds 90 percent. (Gross and Simmons, 2007) Since bias stems from closely held ideology, you can be sure that these students are getting a healthy dose of progressivism, too. In order to be part of the conversation, you have to preserve your place at your university, and for that reason, you must research your institution's policies on academic freedom and use them to preserve your position at university.

In order to counteract the over-indulgence of progressivism at university, both ideologies need to be openly discussed so that students can see each ideology side-by-side, and decide for themselves which ideology works better for them as individuals as well as their larger community. Open forum workshops, with faculty discussing progressivism and capitalism, where students can listen and chime in, will go far to reveal the underlying falsehoods progressives rely on to fool students. We know we will not probably change our colleague's mind about progressivism, the important point, is to fully reveal progressivism to the students, whose mind can be changed. Using a free market textbook will go a long way to counteracting the negativism progressives use against their capitalist colleagues. Students are moved by emotion, not data. So, show them what happens to the pets in countries suffering under progressive policies.

Finally, if you love freedom and liberty, and want to keep teaching your students these ideas, use the rules and policies protecting academic freedom at your university to shield and support your own individual academic freedom.
Eventually it will become apparent that free market economic policies work best; in the market place the idea that works best will be the idea supported freely by the greatest number of people. Over time, eventually, the whole idea of progressivism will just diminish as that ideology falls into the dustbin of history.

\section{REFERENCES}

[1] Gross, Neil, and Solon Simmons. 2007. "The Social and Political Views of American Professors,” Working Paper, September 2007.

[2] Herzog, Karen. and Bruce Vielmetti. 2018. "Wisconsin Supreme Court sides with Marquette professor John McAdams in freespeech case,” Milwaukee Journal Sentinel, July 6, 2018,https://www.jsonline.com/story/news/educatio n/2018/07/06/marquette-professor-john-mcadams-prevailsacademic-freedom-case/759800002/

[3] Hutcheson, Philo. 2018. “Academic Freedom and Tenure Roots of Academic Freedom, Restrictions on Academic Freedom, Tenure,” http://education.stateuniversity.com/pa ges/1724/Academic-Freedom-Tenure.html

[4] Johnson, Paul. 1998. A History of the American People, New York, HarperCollins, 1998.

[5] Johnson, Paul. 1989. Intellectuals, New York, HarperCollins, 1989.

[6] Levinson, Rachel. 2007. "Academic Freedom and the First Amendment,” Presentation to the AAUP Summer Institute, July 2007.

[7] Marx, Karl. 1976/1845. Theses on Feuerbach, Peking, Foreign Language Press, 1976

[8] Marx, Karl, and Friedrick Engels. 2008/1848. The Communist Manifesto, London, Pluto Press, 2008

[9] Moybihan, Donald P. 2017. "Who’s Really Placing Limits on Free Speech?” New York Times, January 9, 2017 https://www.nytimes.com/2017/01/09/opinion/whos-really -placing-limits-on-free-speech.html

[10] Piper, Greg. 2018. “University can’t guarantee 'academic freedom' and then revoke it for PR reasons, state high court rules,” The College Fix, July 6, 2018 http://thecollegefix.com/post/46546/

[11] Rand, Ayn. 1957. Atlas Shrugged, New York, New York: Signet, New American Library a division of Penguin Group, 1992

[12] Shaffer, Frederick P., 2010. "A Guide to Academic Freedom," a brief written by the General Counsel and Senior Vice Chancellor for Legal Affairs, The City University of New York.

[13] Smith, Adam. 1776. The Wealth of Nations, $5^{\text {th }}$ edition, edited and annotated by Edwin Cannan in 1904. New York, New York: Bantamm Dell, 2003.

[14] Yergin, Daniel, and Joseph Stanislaw. 1998. The Commanding Heights, New York, Simon \& Schuster. 
[15] U.S. Constitution, Amendment 1, ratified December 15, 1791, https://nccs.net/blogs/americas-founding-documents/bill-of -rights-amendments-1-10

[16] Volokh, Eugene. 2018. "Marquette University 'Breached Its Contract with Dr. McAdams When It Suspended Him for Engaging in Activity Protected by the Contract's Guarantee of Academic Freedom,” Reason, July 6, 2018

i This research received no specific grant from any funding agency in the public, commercial, or not-for-profit sectors. 